\title{
Teknik Wawancara Dalam Studi Etnoarkeologi
}

\section{Hari Lelono}

Keywords: ethnoarchaeology, interview, data gathering, method, theory, practices

\section{How to Cite:}

Lelono, H. (2000). Teknik Wawancara Dalam Studi Etnoarkeologi. Berkala Arkeologi, 20(1), 8-14. https://doi.org/10.30883/jba.v20i1.802

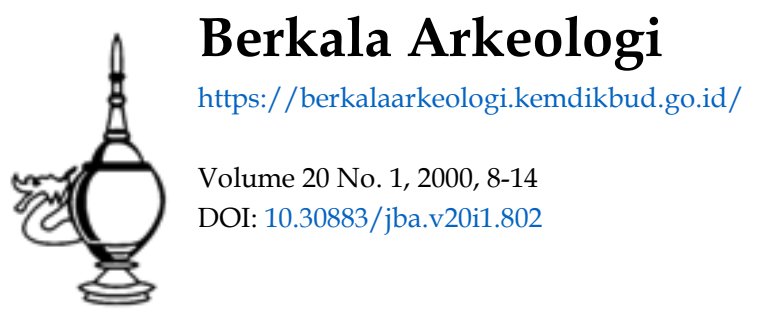

\section{(c) (i) (3)}

This work is licensed under a Creative Commons Attribution-NonCommercial-ShareAlike 4.0 International License. 


\title{
TEKNIK WAWANCARA DALAM STUDI ETNOARKEOLOGI
}

\author{
T.M. Hari Lelono \\ (Balai Arkeologi Yogyakarta)
}

\section{Pendahuluan}

Penelitian arkeologi merupakan penelitian yang sangat penting guna merekontruksi sejarah kehidupan manusia pada masa lampau melalui budaya materi yang ditinggalkan. Data yang diperoleh tersebut jika lengkap dan utuh sangat menguntungkan bagi seorang peneliti, tetapi biasanya hal tersebut sangat jarang diperoleh, karena budaya materi yang ditinggalkan tersebut kebanyakan tidak lengkap yang disebabkan oleh umur, korosi, kerusakan oleh tangan manusia atau oleh alam. Data arkeologi yang dapat diamati sekarang sebenarnya telah melalui suatu perjalanan panjang dari sistem perilaku atau konteks sistem masa lalu, sampai ditemukan oleh arkeolog masa sekarang dalam konteks arkeologi. Ciri-ciri dari konteks arkeologi adalah dapat diamati pada masa sekarang, sementara konteks sistem masa lalu harus dicapai melalui penyimpulan (Schiffer, 1976).

Dalam perjalanan itu terdapat faktor-faktor dan proses yang dapat mengakibatkan terjadinya transformasi data arkeologi: artefak-artefak mengalami perpindahan tempat, perubahan bentuk, pengurangan dan penambahan jumlah, dan pertukaran hubungan satu dengan lainnya (Mundardjito, 1982). Oleh beberapa faktor tersebut menyebabkan informasi data arkeologi yang sampai pada kita sangat terbatas.

Dalam menjawab permasalahan arkeologi, dapat menggunakan model analogi yaitu usaha menjajarkan dua obyek atau peristiwa masa sekarang dengan masa lalu, didasarkan atas persamaan bentuk, relasi, dan lingkungan (Ascher 1962, Mundardjito 1980). Model penelitian ini telah menghasilkan strategi penelitian analogi etnografi yang dilakukan dengan melalui pendekatan langsung (direct historical approach) dan pendekatan lintas budaya (cross cultural proceses). Kedua pendekatan ini berbeda jangkauan daerah penelitiannya. Pendekatan yang pertama melakukan penelitian guna memperoleh informasi atau pernyataan khusus yang digunakan untuk melakukan interpretasi yang harus diterapkan pada daerah yang memiliki kesinambungan sejarah. Sebaliknya, pendekatan kedua, lintas budaya melakukan penelitiannya guna memperoleh informasi bersifat umum, di daerah yang tidak dibatasi oleh ruang dan waktu, dengan tujuan untuk memperoleh dalil (Wibisono, 1985).

Dalam konteks etnoarkeologi data yang dibutuhkan adalah informasi sebanyakbanyaknya tentang konsep, dan persepsi, oleh karena itu ditekankan pada penjaringan data lewat informan bukan pada responden. Dua hal tersebut sangat penting, karena 
mempunyai implikasi yang sangat berbeda. Informan adalah orang yang dapat memberikan informasi seluas-luasnya berdasarkan pada persepsi budaya yang dimiliki. Sedangkan, responden adalah orang yang memberi respon kepada peneliti, sehingga data yang diperoleh adalah sesuai dengan angan-angan/konsep yang dimiliki oleh peneliti. Sementara itu, data yang dibutuhkan adalah untuk menjembatani budaya materi vang ditinggalkan (material culthure) data tersebut berupa keteranganketerangan, sehingga akan lebih tepat kalau menggunakan informan. Syarat-syarat sebagai informan yang baik di dalam penelitian ada ketentuan yang harus dipenuhi. Memang, idealnya ketentuan yang akan di bahas di bawah memenuhi seluruh persayaratn, tetapi jika tidak terpenuhi seluruhnya tidak mengurangi validitas dari data/ informasi yang diperlukan.

\section{Pedoman wawancara}

Dalam melakukan wawancara etnograf selalu menggunakan pedoman wawancara yang berisikan materi pokok pertanyaan yang akan diajukan berdasarkan pada permasalahan yang akan diteliti. Pedoman wawancara dapat berupa catatan maupun cukup diingat dalam pikiran. Namun untuk menghindari kealpaan peneliti sebaiknya dicatat. Materi pokok pedoman wawancara adalah:

1) Bersifat umum; tentang kondisi fisik situs arkeologi, lingkungan sekitarnya, fisik maupun sosial budaya masyarakat.

2) Berisikan tentang data pribadi responden/Identitas Responden/ Informan; antara lain; nama, umur, jenis kelamin, agama, pekerjaan, status, alamat;

3) Materi yang dijadikan sasaran dalam penelitian (tergantung pada konteks penelitian yang dilakukan; selalu dimulai dengan pertanyaan siapa, kapan, dimana, bagaimana, dan mengapa ?;

4) Menyangkut peralatan yang digunakan; jenis, model/ bentuk, banyaknya (jumlah), bahan, warna, dan kegunaan/ fungsi;

5) Berisikan tentang; siapa pengikutnya, siapa pemimpinya, dari mana asalnya, tujuannya, dan lamanya/ waktu yang diperlukan;

6) Berisikan catatan tambahan yang diperlukan, misalnya pada aspek apa yang perlu penekanan-penekanan (stressing) khusus untuk dilakukan cek dan crossing jawaban.

\section{Pentingnya Wawancara}

Penelitian antropologi dalam melakukan pengumpulan data menggunakan dua cara, yakni: metode pengamatan terlibat (partisipasi aktif) dan wawancara mendalam (dept interview). Pengamatan terlibat, yakni peneliti terlibat langsung dalam kegiatan atau masalah yang akan diteliti misalnya terlibat dalam upacara, pengolahan sawah, rumah, 
dan acara ritual lainnya. Dalam pengamatan tersebut dapat merekam segala aktivitas yang dilakukan oleh kelompok masyarakat/individu yang bersangkutan. Setelah melakukan pengamatan terlibat/partisipasi peneliti dapat melanjutkan pengumpulan data dengan cara melakukan wawancara. Wawancara yang diperlukan guna memperoleh data yang holistik/luas perlu wawancara mendalam, dengan sifat pertanyaan yang 'terbuka'.

Adapun dipandang dari sudut bentuk-bentuk pertanyaan-pertanyaannya, dapat dibagi ke dalam dua golongan, ialah (1) Wawancara tertutup atau closed interview dan (2) Wawancara terbuka atau open interview. Wawancara tertutup terdiri dari pertanyaanpertanyaan yang bentuknya itu sedemikian rupa sehingga kemungkinan jawab dari responden atau informannya amat terbatas. Kadang-kadang malahan ada pertanyaanpertanyaan yang sedemikian rupa bentuknya, sehingga para responden hanya dapat menjawab "ya" atau "tidak". Adapun wawancara terbuka adalah lawannya, dan terdiri dari pertanyaan-pertanyaan yang sedemikian rupa bentuknya sehingga responden atau informan tidak terbatas dalam jawaban-jawabannya kepada beberapa kata-kata saja, atau hanya kepada jawab "ya" atau "tidak" saja, tetapi dapat mengucapkan keterangan-keterangan dan cerita-cerita yang panjang (Koentjaraningrat, 1981).

Setelah menyiapkan bahan yang akan ditanyakan, tidak kalah penting adalah bagaimana memilih informan yang baik. Menurut Spradly, dalam Bambang Sulistyanto (1998) sekurangnya ada lima persyaratan untuk memilih informan, sebagai berikut:

Pertama, enkulturasi penuh.

Artinya, informan tersebut harus berasal dari kebudayaan yang menjadi setting penelitian. Informan yang beik mengetahui budaya mereka dengan tepat tanpa harus memikirkannya. Jawaban yang diberikan atas pertanyaan peneliti, bersifat spontanitas yang mampu mewakili budaya setempat yang dipelajari melalui pengalamannya. Dengan demikian semakin terenkulturasi secara penuh, maka semakin baik informan tersebut. Pemilihan informan berasal dari kebudayaan setempat, merupakan persyaratan yang tidak dapat ditawar lagi, jika peneliti tidak ingin terperosok pada perolehan informasi yang mencerminkan kebudayaan luar.

\section{Kedua, keterlibatan langsung}

Pada waktu penelitian berlangsung, informan sedang terlibat secara langsung dalam kebudayaan yang sedang diteliti. Persyaratan ini sangat penting, karena dengan keterlibatan suasana budaya akan mempengaruhi pola pemiiran informan dalam memberikan penjelasan. Informan yang tidak lagi terlibat dalam kebudayaan masyarakat yang diteliti, sukar untuk mengungkapkan fenomena budaya yang menjadi obyek kajian etnografer. Informan yang telah meninggalkan suasana budaya, hanya dapat mengingat garis besar secara umum berbagai aktivitas yang sedang berlangsung 
dan ini dikawatirkan dapat melakukan banyak penyimpangan dari budaya yang pernah dimilikinya dulu.

Ketiga, latar belakang budaya yang belum kenal. Maksudnya adalah informan tersebut haruslah memiliki latar belakang budaya yang belum dikenal oleh peneliti. Dengan perbedaan budaya tersebut, baik peneliti maupun informan dapat secara leluasa mengungkapkan kemauan dan pengetahuannya secara murni. Hal ini berbeda jika peneliti memilih informan yang memiliki latar belakang budaya yang sama dengan peneliti, dikawatirkan akan menimbulkan masalah dalam wawancara. Masalah tersebut ialah informan akan mempersiapkan informasi mengenai apa yang diperlukan oleh peneliti.

Keempat, cukup waktu. Informan haruslah memiliki cukup waktu untuk diwawancarai. Realitas di lapangan sering kita jumpai ada informan yang sangat potensial, tetapi tidak memiliki waktu untuk diwawancarai, sehingga wawancara dilakukan disela-sela kesibukannya. Demikian pula sebaliknya, terdapat informan yang kurang luas pengetahuannya tetapi banyak waktu yang tersedia untuk diwawancarai. Untuk mengatasi masalah ini dapat dipergunakan informan ganda yang berbeda tetapi memiliki pengetahuan budaya yang sama. Hasilnya kemudian dibandingkan.

Kelima, non analitik. Sebaiknya dihindari informan yang dalam penjelasannya disertai analitis di luar kerangka pikir kebudayaannya. Informan yang baik dan perlu diangkat adalah informan yang menggunakan bahasanya untuk melukiskan peristiwaperistiwa dan tindakannya yang tidak pernah disertai analisis makna dari fenomena tersebut. Namun demikian untuk membantu menemukan pola makna secara tepat terhadap penjelasan informan, maka dapat diangkat informan yang mampu menyajikan analisis tentang gejala dari perspektif budaya masyarakatnya sendiri. Pengungkapan teori lokal ini sangat penting guna mempertajam kajian peneliti.

Sebagai alat untuk membantu perolehan informasi penting guna melengkapi data sebelumnya, perlu dilakukan wawancara. Metode ini tidak sesederhana seperti yang dibayangkan, banyak ketentuan yang harus dipenuhi dan dipersiapkan secara matang oleh peneliti. Dalam konteks tersebut menyangkut beberapa hal yang bersifat operasional antara lain: (1) siapa informannya, (2) bentuk pertanyaan, $(3$, ) alat-alat yang digunakan, dan. (4) penampilan pewawancara. Secara rinci dapat dijelaskan sebagai berikut;

\section{(1). Siapa informannya}

Informan adalah orang yang memberikan informasi penting berkaitan dengan masalah yang dijadikan obyek penelitian, Informan dapat tinggal di dalam lingkungan masyarakatnya maupun dapat pula di luar masyarakatnya. Informan yang tingal dalam 
lingkungannya, adalah para anggota masyarakat setempat dan tokoh-tokoh formal maupun informal seperti; dukun, balean, ketua adat, lurah, bekel, carik, dan lain sebagainya. Dalam konteks yang terakhir biasanya ia dapat seorang pakar dalam bidangya yang mengetahui secara benar tentang perilaku, adat istiadat, tatacara, pada masyarakat yang bersangkutan.

Pemilihan/penentuan jumlah informan tidak ada batasan secara tegas yang mengaturnya. Dalam hal ini yang dilakukan seorang peneliti, adalah pemilihan orang yang tepat, oleh karena itu paling tidak harus ada beberapa informan. Sebagai contoh; dapat dipilih informan kunci, dan beberapa informan biasa (jumlahnya lebih banyak). Ketepatan dalam pemilihan informan sangat menentukan kredibcl atau tidaknya data yang diperoleh. Dalam hal ini kejelian peneliti hanus dapat menentukan berapa orang banyaknya individu yang dapat 'mewakili' untuk dijadikan informan inti dan informan biasa.

\section{(2). Bentuk pertanyaan}

Dalam penelitian etnografis, etnograf selalu memperhatikan kondisi dan situasi dari masyarakat yang dijadikan obyek penelitian. Contoh; dalam melakukan penelitian terhadap suatu kelompok masyarakat pedalaman di suatu pulau atau suku tertentu, peneliti hendaknya memperhatikan tata cara dan aturan yang berlaku, guna memperoleh informasi yang diperlukan. Pertanyaan berusaha menggiring/ mengarahkan pada sasaran dalam konteks pikiran-pikiran dan persepsi masyarakat adat. Usahakan agar tidak membosankan dan menggunakan catatan serta bahasa yang disesuaikan dengan masyarakat setempat. Hal penting dalam melakukan pertanyaan/ wawancara adalah pertanyaan-pertanyaan hendaknya bersifat 'terbuka', artinya; memberi kesempatan seluas-luasnya bagi informan untuk menceritakan dan mengutarakan jalan pikiran, persepsi dan fenomena-fenomena yang ada dalam pikirannya. Dalam hal ini yang perlu diperhatikan adalah jangan sampai pernyataan yang disampaikan ke luar dari konteks masalahnya, sehingga lebih efisien.

\section{(3) Alat-alat yang digunakan}

Perlengkapan utama yang diperlukan dalam melakukan studi etnoarkeologi adalah alat-alat tulis, fotografi, dan tape recorder, alat-alat tersebut sangat diperlukan untuk merekam/ mengkaver informasi maupun tinggalan budaya materi, seperti bangunan, sesaji, alat-alat rumah tangga/ pertanian, dan benda-benda yang disakralkan (patung, pohon, batu, sungai, dan lain sebagainya). Perlu diperhatikan pula, bahwa penggunaan alat-alat pembantu, tergantung pada situasi dan kondisi masyarakatnya. Pada masyarakat di pedalaman, biasanya mereka akan merasa takut, curiga, dan terganggu dengan adanya peralatan tersebut, sehingga dapat menganggu proses wawancara yang sedang dilakukan. Hal tersebut dapat berakibat vatal dan mengurangi validitas dari data yang dibutuhkan. 


\section{(4) Penampilan dan waktu}

Penampilan peneliti perlu diperhatikan menyangkut beberapa hal, seperti; cara berpakaian, berkomunikasi dan sopan santun. Cara berpakaian sebaiknya disesuaikan dengan kondisi masyarakat dan situasi yang sedang berlangsung di masyarakat yang bersangkutan, sebagai misal masyarakat tersebut sedang melangsungkan upacara dengan pakaian tertentu, peneliti harus menyesuaikan diri dengan terlebih dahulu minta ijin boleh tidaknya memakai pakaian adat kepada tokoh masyarakat setempat. Cara berkomunikasi usahakan menggunakan bahasa daerah setempat dan gunakan bahasa yang sederhana namun mudah dipahami oleh informan, sehingga pertanyaanpertanyaan yang muncul mudah dijawab dan memberikan informasi yang lengkap. Sopan santun adalah hal yang sangat sensitif, karena satu masyarakat/ suku dengan lainnya terdapat perbedaan-perbedaan yang seringkali bertolak belakang. Hal tersebut perlu dilakukan agar penampilan, etika, dan sopan santun yang dilakukan oleh peneliti dapat diterima dengan baik oleh kelompok masyarakat tersebut.

Waktu melakukan pertanyaan yang paling ideal adalah disesuaikan kondisi setempat, biasanya pada kelompok masyarakat petani pada pagi, siang mereka istirahat di rumah/ tegalan, dan sore hari mereka baru berada di rumah. Sehingga waktu yang tepat adalah pada sore hari atau malam hari dengan melakukan pendekatan sebelumnya. Pada sekelompok individu yang sedang melakukan ziarah/ritual keagamaan pada malam hari, sebaiknya peneliti pandai-pandai menggunakan kesempatan yang sangat terbatas tersebut dengan ikut serta/berpartisipasi aktif. Unsur penting dalam hal tersebut diusahakan menciptakan suasana yang santai dan hindarkan ketegangan.

\section{Penutup}

Budaya materi yang ditinggalkan masyarakat kuno (Prasejarah, Klasik dan Islam) banyak yang sudah rusak dan miskin informasi bahkan sudah tertransformasi, apalagi untuk mengungkap tradisi, fungsi dan kegunaan materi tersebut sangat sulit. Oleh karena itu dalam rangka mengungkap/ merekontruksi perliaku sosial, ekonomi, religi, dan pemanfaatan sumberdaya alam, perlu dengan pendekatan wawancara terhadap responden/ informan. Pendekatan yang biasanya dilakukan oleh antropolog atau etnograf tersebut menunjang dalam mengungkap aktivitas, perilaku masyarakat masa lalu dengan bantuan data berupa persepsi, aktivitas, dan tingkah laku pada masyarakat masa kini. Hal tersebut dilakukan dengan cara melakukan analogi. Dalam menganalogikan tersebut tentunya terdapat persyaratan, antara lain paling tidak harus mempunyai unsur budaya yang sama. Dalam konteks tersebut dipandang perlu peneliti menterapkan metode pengamatan terlibat dan wawancara mendalam. Dimaksudkan dalam pengamatan yang dilakukan lebih dahulu akan mendapat 
tambahan permasalahan yang belum kita ketahui sebelumnya, serta dapat menentukan/memilih informan/responden yang diperlukannya.

Penelitian etnoarkeologi dalam kasus tertentu mutlak dilakukan di Indonesia, guna memperoleh gambaran pikiran/konsepsi-konsepsi masyarakat masa lampau. Hal tersebut sebenarnya mudah dilakukan di Indonesia, karena sebagian besar tradisi budaya masa lampau masih berlanjut hingga saat ini.

Berlatar pada kenyataan, bahwa kontribusi yang disumbangkan oleh desiplin ilmu antropologi tersebut dalam mengungkap konsepsi-konsepsi, manusia sebagai individu atau anggota masyarakat, kiranya perlu dilakukan penelitian dengan pendekatan etnoarkeologi, dalam konteks tersebut adalah melakukan wawancara dengan seperangkat alat dan ketentuan yang perlu dirumuskan. Hal tersebut penting, karena di Indonesia tradisi masa lampau masih tampak dilakukan oleh generasi saat ini, utamanya dalam masalah ritual, keagamaan, kebiasaan, dan adat-istiadat, serta dalam beberapa konsep-konsep pembuatan rumah, tempat ibadah, dan lain-lain.

\section{KEPUSTAKAAN}

Koentjaraningrat, Metode-Metode Penelitian Masyarakat, PT. Gramedia, Jakarta. 1981. Pengantar Ilmu Antropologi, Aksara Baru, Jakarta.

Mundardjito, 1981. Etnoarkeologi: Peranannya Dalam Pengembangan Arkeologi di Indonesia, Seminar Sejarah Nasional III, Jakarta, 10--15 November.

Schiffer, M.B, 1978. "Methodological Issues in Ethnoarchaeology", Exploration in Ethnoarchaeology, Albuquerque: University of New Mexico.

Sulistyanto, Bambang, 1999. Teknik Pengumpulan Data Emografi. PIA VIII, Yogyakarta, Februari.

Wibisono, Sonny. Chr, 1985. Metode Penelitian Etnoarkeologi, REMPA II, Pandeglang, Jawa Barat 6 -- 12 Mei. 